\title{
Redox transformations of mercury in an Arctic snowpack at springtime
}

Alexandre J.Poulain, Janick D.Lalonde, Marc Amyot, Justin A. Shead, Farhad Roafie, Parisa A. Ariya

Abstract

We investigated the springtime temporal dynamics of both total mercury $(\mathrm{Hg})$ and gaseous $\mathrm{Hg}$ in snowpacks from the High Arctic. In situ incubation experiments of snow samples indicated that the production of volatile mercury in snow (VMS) was photomediated and occurred in the first $3 \mathrm{~cm}$ of snow. The newly produced VMS (consisting mainly of elemental $\mathrm{Hg}$ ) was partly oxidized back to $\mathrm{Hg}$ (II) when light intensity declined or in the absence of UV radiation, probably through a chain of reactions involving photo-induced radicals and organic compounds in the surface snow. During a 2 week monitoring of total $\mathrm{Hg}$ in surface snow, we observed a sharp increase in total $\mathrm{Hg}$ concentrations, reaching levels 11 times higher than background concentrations, likely as a result of an atmospheric mercury depletion event. Stratigraphic depth profiles indicated that this increase was restricted to the first $2 \mathrm{~cm}$ of the snowpack. Total $\mathrm{Hg}$ levels subsequently decreased by $92 \%$, reaching background concentrations within 2 days after this event. The photoproduction rate of VMS calculated on the basis of this episode could account for subsequent daily loss of total $\mathrm{Hg}$ from the surface of the snowpack.

\section{Introduction}

Due to its ability to travel over long distances in the atmosphere, $\mathrm{Hg}$ is a global pollutant. Over the last decade, a major concern arose from the discovery of atmospheric mercury depletion events (MDE) in polar (Schroeder et al., 1998; Ebinghaus et al., 2002) and subpolar regions (Poissant and Pilote, 2003). These events partly result from the oxidation of atmospheric elemental $\mathrm{Hg}, \mathrm{Hg}(0)$, through reactions with halogens such as bromine (Lindberg et al., 2001; Ariya et al., 2002, Ariya et al., 2002). These MDEs can lead to an important deposition of $\mathrm{Hg}$ in snowpack ( $\underline{\mathrm{Lu}}$ et al., 2001), potentially causing the contamination of terrestrial and aquatic systems upon snowmelt. However, the post-deposition $\mathrm{Hg}$ dynamics in Arctic snow is not fully understood. Recent evidence (Lindberg et al., 2002; Scott, 2003) suggests that newly deposited $\mathrm{Hg}$ is highly bioavailable, increasing the need to better understand its fate, whether it results from mercury depletion events or from wet and dry depositions.

In temperate urban and remote pristine regions, Lalonde et al., 2002, Lalonde et al., 2003 have shown that within 24 h, approximately $50 \%$ of the newly deposited $\mathrm{Hg}$ could be efficiently recycled back to the atmosphere probably through photoreduction. In Arctic regions, Steffen et al. (2002) proposed that reactive gaseous mercury (RGM), thought to be the main product of MDEs (Lindberg et al., 2001), could be recycled from the surface of the snowpack back to gaseous elemental mercury (GEM), also through photoreduction. Dommergue et al. (2003) and Ferrari et al. (2004) demonstrated diurnal cycles of interstitial gaseous mercury at the surface and at depth in the snowpack of a sub-Arctic region. Another, yet unexplored, mechanism is the photooxidation of $\mathrm{Hg}(0)$ in snow. This process can occur in surface waters and snow, and is thought to be enhanced by chloride ions (Lalonde et al., 2001, Lalonde et al., 2003, Lalonde et al., 2004). The purpose of this paper is (i) to establish the temporal dynamics of both total $\mathrm{Hg}$ and elemental $\mathrm{Hg}$ at the surface and within snowpacks in the High Arctic, during and after a MDE; and (ii) to determine whether photooxidation of $\mathrm{Hg}$ occurs in Arctic snowpacks. 


\section{Experimental section}

\subsection{Sampling sites}

Our sampling sites were located on Cornwallis Island, Nunavut, Canada. We monitored cations $\left(\mathrm{Al}^{3+}, \mathrm{Ca}^{2+}, \mathrm{Fe}^{3+}, \mathrm{K}^{+}\right.$, $\mathrm{Mg}^{2+}, \mathrm{Mn}^{2+}, \mathrm{Na}^{+}$and $\left.\mathrm{Zn}^{2+}\right)$ as well as anions $\left(\mathrm{Cl}^{-}, \mathrm{NO}_{3}{ }^{-}, \mathrm{NO}_{2}{ }^{-}, \mathrm{Br}^{-}\right.$and $\left.\mathrm{SO}_{4}{ }^{2-}\right)$ on a regular basis at Mel site, located $74^{\circ} 43^{\prime} \mathrm{N}-95^{\circ} 00^{\prime} \mathrm{W}$. We also sampled Small Lake $\left(74^{\circ} 45^{\prime} \mathrm{N}-95^{\circ} 03^{\prime} \mathrm{W}\right)$, an inland site $\left(75^{\circ} 05^{\prime} \mathrm{N}-93^{\circ} 43^{\prime} \mathrm{W}\right)$ and a coastal $\left(75^{\circ} 02^{\prime} \mathrm{N}-96^{\circ} 20^{\prime} \mathrm{W}\right)$ site. Organic compounds were analysed from surface snow sampled at the south shoreline of North Lake $\left(74^{\circ} 50^{\prime} \mathrm{N}-95^{\circ} 05^{\prime} \mathrm{W}\right)$ (Fig. 1).

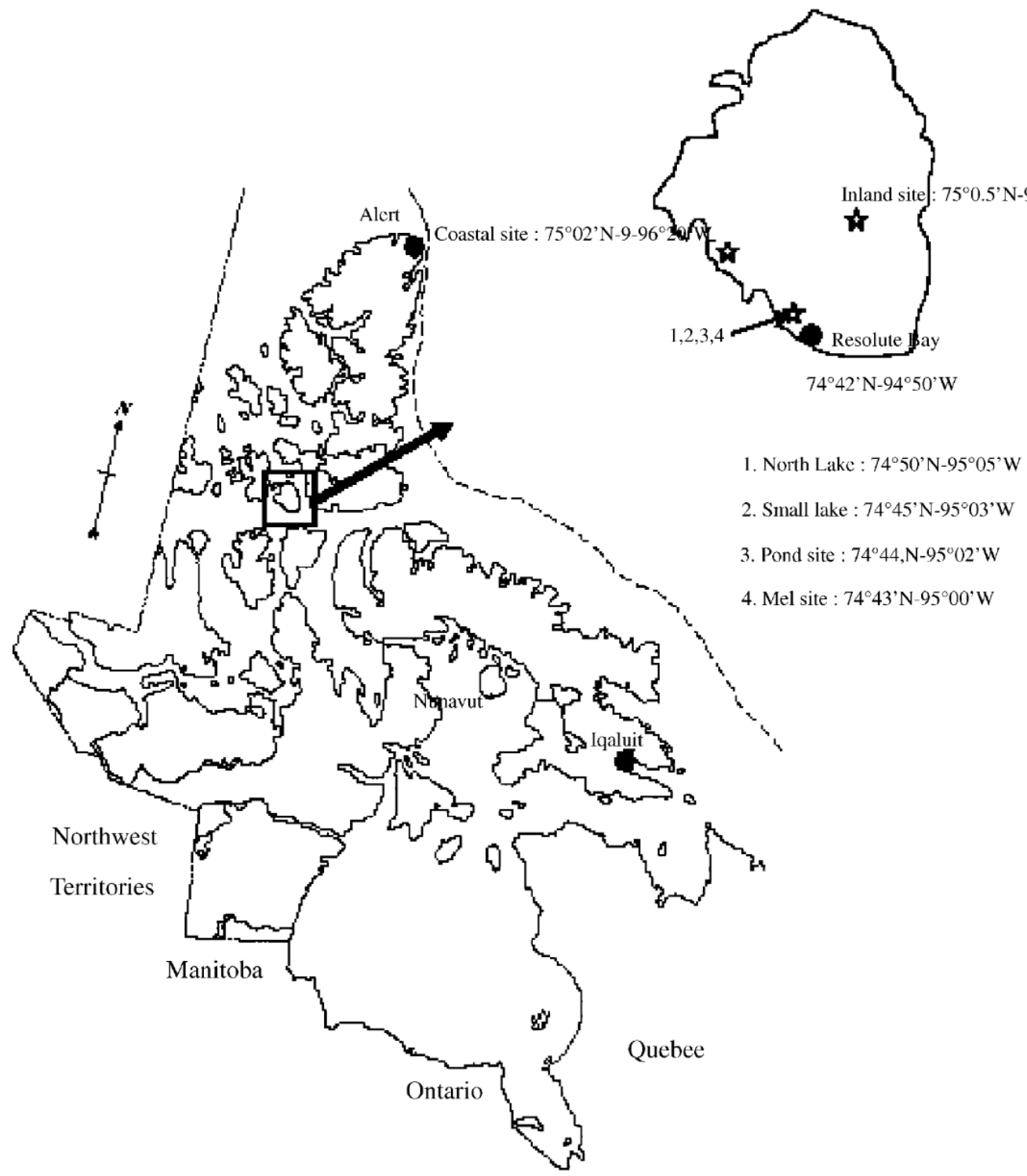

Fig. 1. Location of Cornwallis Island. Stars represent sampling sites. http://atlas.gc.ca/site/english/maps/reference/outlineprov_terr/ index.html.

\subsection{Sampling, monitoring and incubations}

Monitoring was done by collecting triplicate snow samples from the surface of the snowpack. For depth profiles, samples were taken from each snow stratum. Snow strata were determined by the state of metamorphism of the snow grains, as defined the international classification of seasonal snow on the ground (Colbeck et al., 1985).

Snow for cation analysis was collected in $30 \mathrm{~mL}$ HDPE Nalgene bottles and acidified to $0.1 \%$ with $\mathrm{HNO}_{3}(64 \%)$. Snow for anion analysis was collected in $20 \mathrm{~mL}$ disposable samples vials. All samples were kept at $4{ }^{\circ} \mathrm{C}$ until analysed. Snow samples for $\mathrm{Hg}$ analysis were taken using Teflon bottles previously acid-washed and thoroughly rinsed with milliQ water $(\mathrm{R}>18.2 \mathrm{M} \Omega \mathrm{cm}-1)$. 
https://www.sciencedirect.com/science/article/pii/S1352231004008544

Experiments consisted of incubating clear and black 1 L FEP Teflon bottles for various lengths of time under different light treatments. During incubation, bottles were placed horizontally with their cap pointing north. Bottles were regularly and gently rotated every $30 \mathrm{~min}$ to optimize the distribution of light through the sample. Incubations lasted for 6-8 h and usually started between 8:30 am and 10:00 am. Mylar filters were used to cut most of the UVB radiation (280-320 nm) and UV-Lee filters model 226 were used to prevent UV radiation (280-400 nm) from reaching the samples. PAR (400-700 nm) was recorded every 1 or 5 min using a Smart Sensor HOBO ${ }^{\circledR}$ connected to a data logger.

\subsection{Chemical analyses}

In order to minimize losses of gaseous mercury in snow (VMS) during the analysis, solid snow was sparged directly in the sampling bottle by tightly inserting a porous glass rod into the bottle. We used a zero-air generator (Tekran model 1100) to sparge the sample, at a flow rate of $1.5 \mathrm{~L} \mathrm{~min}^{-1}$. The sample was heated during sparging, by placing it in a hot water bath (approx. $30^{\circ} \mathrm{C}$ ). The bottle was connected to an automated atmospheric mercury analyser (Tekran ${ }^{\mathrm{TM}}$ Model 2537) in order to monitor the decrease of VMS over time (one reading every 5 min). The experimental design was modified from that of Lindberg et al. (2001). The sparging step was stopped when snow had melted and when concentrations plateaued at zero. Here we report VMS values in moles per volume of melt water instead of moles per volume of snow, in order to correct for the difference in snow density. The working detection limit of this method was calculated as $<0.01 \mathrm{pmol} \mathrm{L}^{-1}$ or three times the standard deviation of ten system blanks ran on snow with low $\mathrm{Hg}$ levels.

Total Hg concentrations in snowmelt were quantified using the method described by Lalonde et al. (2003) and based on Gill and Bruland (1990), using a mercury fluorescence detector (Tekran ${ }^{\text {TM }}$ Model 2500). Briefly, Hg in unfiltered snow samples was reduced using $1 \% \mathrm{NaBH}_{4}(\mathrm{w} / \mathrm{v})$ and $4 \mathrm{M} \mathrm{NaOH}$. Approximately $100 \mathrm{~mL}$ of snowmelt was poured into a $250 \mathrm{~mL}$ glass bubbler and sparged for $20 \mathrm{~min}$ with clean air from a Hg-free air generator (Tekran ${ }^{\mathrm{TM}} \mathrm{Model}$ 1100 ) additionally stripped of $\operatorname{Hg}(0)$ by passage over a gold filter at a flow rate of $\approx 1 \mathrm{~L} \mathrm{~min}^{-1}$. The working detection limit of this method was calculated as $0.5 \mathrm{pmol} \mathrm{L}^{-1}$ or three times the standard deviation of ten procedural blanks.

Anions were analysed by ion chromatography using a DIONEX ICS 2000. $25 \mu \mathrm{L}$ of melted snow were introduced in the injection loop and separation occurred through an AS-17 column topped with a AG-17 precolumn. The elution step involved the passage of a $\mathrm{KOH}$ solution with a gradient of concentration from 15 to $30 \mathrm{mmol} \mathrm{L}^{-1}$. Cations were analysed using an inductively coupled plasma atomic emission spectrometer (ICP-AES Vista AX) using an internal standard of Yttrium $\left(5 \mathrm{mg} \mathrm{L}^{-1}, 371 \mathrm{~nm}\right)$.

Organic compounds in surface snow were analysed using two different methods: (a) electron spray ionization mass spectrometry (ESI-MS); (b) solid phase micro extraction (SPME). For the ESI-MS method, $5 \mu \mathrm{L}$ of melted snow was injected into the electron spray of mass spectrometer (Thermoquest Finigan LC QDUO). For the SPME method, manual extraction was performed with several replacement fibre assemblies (Supelco). Four different types of fibres were compared: polyacrylate $(85 \mu \mathrm{m})$, polydimethyl siloxane $(100 \mu \mathrm{m})$, polydimethyl siloxane/divinyl benzene $(65 \mu \mathrm{m})$ carbowax/divinyl benzene $(65 \mu \mathrm{m})$. The fibres were conditioned prior to use as recommended by the manufacturer by heating them at different temperatures $\left(250-300{ }^{\circ} \mathrm{C}\right.$ ) for periods between $30 \mathrm{~min}$ and $2 \mathrm{~h}$ in gas chromatograph injection port. After conditioning the fibres, they were inserted into the solution under magnetic stirring using a Teflon bar and magnetic stirrer. After $5 \mathrm{~h}$ adsorption, the fibres were injected directly into the injection port of the gas chromatograph-mass spectrometer (GC-MS) in the splitless mode and held isothermally at $250{ }^{\circ} \mathrm{C}$. Desorption time was 5 min. Chromatographic analyses were performed using Hewlett Packard GC (HP 6890) equipped with a splitless injector and mass spectrometric detection (HP 5973 MSD). The GC was fitted with a $30 \times 0.25 \mathrm{~mm}$ i.d. column coated with $5 \%$ phenyl methyl siloxane (HP-5 MS). The column was operated at a constant flow $\left(1.5 \mathrm{~mL} \mathrm{~min}{ }^{-1}\right)$ of ultra high purity helium. The oven temperature was increased by $5^{\circ} \mathrm{C} \min ^{-1}$ up to $200{ }^{\circ} \mathrm{C}$. Conditions for the mass selective detector were as follows: transfer line temperature $280{ }^{\circ} \mathrm{C}, 70 \mathrm{eV}$ electron impact, electron multiplayer voltage $2180 \mathrm{~V}$, mass range for full scan 10-550 a.m.u.

\section{Results}

\subsection{Chemical composition of snow}

Concentrations of alkaline (e.g. $\left.\mathrm{Na}^{+}\right)$and alkaline-earth (e.g. $\left.\mathrm{Ca}^{2+}, \mathrm{Mg}^{2+}\right)$ cations as well as of metals $\left(\mathrm{Al}^{3+}, \mathrm{Zn}^{2+}\right.$, $\mathrm{Fe}^{3+}$ and $\mathrm{Hg}^{2+}$ ) covered one to two orders of magnitude (max:min: 38 to 190; Table 1). Anion concentrations were less variable, except for chloride and sulphate (max:min 17 and 19 fold, respectively). The dominant cations were $\mathrm{Ca}^{2+}\left(3.6 \mathrm{mg} \mathrm{L}^{-1}\right)$, followed by $\mathrm{Na}^{+}\left(1.15 \mathrm{mg} \mathrm{L}^{-1}\right)$ and $\mathrm{Mg}^{2+}\left(0.96 \mathrm{mg} \mathrm{L}^{-1}\right)$. The dominant anions were $\mathrm{Cl}^{-}\left(0.84 \mathrm{mg} \mathrm{L}^{-1}\right)$ followed by $\mathrm{NO}_{3}{ }^{-}\left(0.30 \mathrm{mg} \mathrm{L}^{-1}\right)$ and $\mathrm{SO}_{4}{ }^{2-}\left(0.28 \mathrm{mg} \mathrm{L}^{-1}\right)$. $\mathrm{pH}$ ranged from acidic to strongly alkaline values (6.2 to 9.5). Amongst the identified organic molecules (Table 2), aldehydes, ketones, nitriles, aromatics, alkanes, alkenes, and halocarbons were observed. 
https://www.sciencedirect.com/science/article/pii/S1352231004008544

Table 1

Chemical composition of surface snow and pond water from 6 June to 21 June 2003. All concentrations are expressed in $\mathrm{mg} \mathrm{L}^{-1}$ expect for $\mathrm{Hg}$ expressed in $\mathrm{pmol} \mathrm{L}^{-1}$

\begin{tabular}{|c|c|c|c|c|c|c|c|c|c|}
\hline $\begin{array}{l}\text { Sampling site } \\
\text { Latitude }(\mathrm{N}) \\
\text { Longitude }(\mathrm{W}) \\
\text { Matrices } \\
\text { Sampling dates }\end{array}$ & $\begin{array}{l}\text { Mel site } \\
74^{\circ} 43 \\
95^{\circ} 00 \\
\text { snow } \\
\text { From } 6 \mathrm{Ju}\end{array}$ & to 21 & & & $\begin{array}{l}\text { Small Lake } \\
74^{\circ} 45 \\
95^{\circ} 03 \\
\text { snow } \\
09 \text { Jun }\end{array}$ & $\begin{array}{l}\text { Inland site } \\
75^{\circ} 05 \\
93^{\circ} 34 \\
\text { snow } \\
10 \text { Jun }\end{array}$ & $\begin{array}{l}\text { Coastal Site } \\
75^{\circ} 02 \\
96^{\circ} 20 \\
\text { snow } \\
11 \text { Jun }\end{array}$ & $\begin{array}{l}\text { All snow samples } \\
\mathrm{max} / \mathrm{min}\end{array}$ & $\begin{array}{l}\text { Pond water } \\
74^{\circ} 44 \\
95^{\circ} 02 \\
\text { water } \\
19 \text { Jun }\end{array}$ \\
\hline & $\min$ & $\max$ & average & SD & & & & & \\
\hline $\mathrm{Al}(+\mathrm{III})$ & 0.004 & 0.316 & 0.135 & 0.133 & 0.010 & 0.005 & 0.006 & 83 & 0.174 \\
\hline $\mathrm{Ca}(+\mathrm{II})$ & 0.133 & 9.211 & 3.636 & 3.477 & 0.365 & 0.048 & 0.180 & 190 & 14.107 \\
\hline $\mathrm{Fe}(+\mathrm{III})$ & 0.002 & 0.227 & 0.088 & 0.087 & 0.011 & 0.006 & 0.005 & 108 & 0.133 \\
\hline $\mathrm{K}(+\mathrm{I})$ & 0.014 & 0.237 & 0.087 & 0.075 & 0.018 & 0.009 & 0.116 & 25 & 0.757 \\
\hline $\mathrm{Mg}(+\mathrm{II})$ & 0.031 & 2.662 & 0.960 & 0.898 & 0.081 & 0.028 & 0.176 & 95 & 4.483 \\
\hline $\operatorname{Mn}(+\mathrm{II})$ & $<0.0002$ & 0.010 & 0.004 & 0.004 & 0.001 & 0.001 & 0.001 & 49 & 0.012 \\
\hline $\mathrm{Na}(+\mathrm{I})$ & 0.027 & 3.456 & 1.153 & 1.336 & 0.322 & 0.216 & 3.780 & 141 & 7.815 \\
\hline $\mathrm{Zn}(+\mathrm{II})$ & 0.001 & 0.017 & 0.006 & 0.005 & 0.022 & 0.030 & 0.020 & 38 & 0.002 \\
\hline $\mathrm{Hg}(+\mathrm{II})( \pm \mathrm{SD})$ & 2.9 & 111.0 & 15.0 & 32.0 & $12.7 \pm 4.46$ & $\mathrm{n} / \mathrm{a}$ & $11.3 \pm 3$ & 38 & $14.8 \pm 0.4$ \\
\hline $\mathrm{pH}$ & 6.16 & 9.52 & 6.86 & & 6.23 & 5.23 & 5.54 & 19,500 & 8.15 \\
\hline $\mathrm{Cl}(-\mathrm{I})$ & 0.145 & 1.361 & 0.841 & 0.417 & 0.647 & 0.677 & 2.751 & 19 & 10.104 \\
\hline $\operatorname{Br}(-\mathrm{I})$ & 0.013 & 0.044 & 0.028 & 0.022 & 0.011 & 0.011 & $<0.004$ & 4 & $<0.004$ \\
\hline $\mathrm{NO}_{2}(-\mathrm{I})$ & 0.008 & 0.032 & 0.015 & 0.010 & 0.007 & 0.011 & $<0.006$ & 4 & $<0.006$ \\
\hline $\mathrm{NO}_{3}(-\mathrm{I})$ & 0.049 & 0.698 & 0.302 & 0.238 & 0.542 & 0.742 & $\mathrm{n} / \mathrm{a}$ & 15 & 0.242 \\
\hline $\mathrm{SO}_{4}(-\mathrm{II})$ & 0.044 & 0.706 & 0.281 & 0.239 & 0.400 & 0.245 & 0.766 & 17 & 6.661 \\
\hline
\end{tabular}


Table 2

Organic compounds extracted from surface snow sample, June, 2003

\begin{tabular}{|c|c|c|c|}
\hline $\begin{array}{l}\text { Organic } \\
\text { Compound }\end{array}$ & $\begin{array}{l}\text { Enpirical } \\
\text { Formula }\end{array}$ & $\begin{array}{c}\text { Molecular } \\
\text { Mass }\end{array}$ & $\begin{array}{l}\text { Molecular } \\
\text { Structure }\end{array}$ \\
\hline 1,3,5-Cyclohepatriene & $\mathrm{C}_{7} \mathrm{H}_{8}$ & 92 & \\
\hline Choloro bezene & $\mathrm{C}_{6} \mathrm{Cl}_{5}$ & 112 & \\
\hline 1-ethyl, 3-methyl benzene & $\mathrm{C}_{9} \mathrm{H}_{12}$ & 120 & \\
\hline 3-Allylcyclohexane & $\mathrm{C}_{9} \mathrm{H}_{14}$ & 122 & \\
\hline $\begin{array}{l}\text { 4,6-di (1,1-dimethylethyl)- } \\
\text { 2-methyl Phenol }\end{array}$ & $\mathrm{C}_{15} \mathrm{H}_{24} \mathrm{O}$ & 220 & \\
\hline $\begin{array}{l}\text { 4(1-methylethenyl) } \\
1 \text {-Cyclohexene 1-Carboaldehyde }\end{array}$ & $\mathrm{C}_{10} \mathrm{H}_{14} \mathrm{O}$ & 150 & \\
\hline $\begin{array}{l}\text { 3,4-dihydro-6-m } \\
\text { 1(2H)-Naphtalenone }\end{array}$ & $\mathrm{C}_{11} \mathrm{H}_{12} \mathrm{O}_{2}$ & 176 & \\
\hline $\begin{array}{l}\text { 2,2,3-trimethyl } 3 \text { - } \\
\text { Cyclopentene- } 1 \text {-acetaldehyde }\end{array}$ & $\mathrm{C}_{10} \mathrm{H}_{16} \mathrm{O}$ & 152 & \\
\hline Hexanenitrile, 5-methyl & $\mathrm{C}_{7} \mathrm{H}_{13} \mathrm{~N}$ & 111 & \\
\hline N-dibutyl Formamide & $\mathrm{C}_{9} \mathrm{H}_{19} \mathrm{NO}$ & 157 & \\
\hline Heptanal & $\mathrm{C}_{7} \mathrm{H}_{14} \mathrm{O}$ & 114 & \\
\hline Octanal & $\mathrm{C}_{8} \mathrm{H}_{16} \mathrm{O}$ & 128 & \\
\hline Nonanal & $\mathrm{C}_{9} \mathrm{H}_{18} \mathrm{O}$ & 142 & \\
\hline Tridecanal & $\mathrm{C}_{13} \mathrm{H}_{26} \mathrm{O}$ & 198 & \\
\hline
\end{tabular}

3.2. Temporal and spatial distribution of total $\mathrm{Hg}$ and VMS concentrations at Mel site Total $\mathrm{Hg}$ concentrations remained below $15 \mathrm{pmol} \mathrm{L}^{-1}$ from 4 June to 24 June (Fig. 2) and were consistent with concentrations observed by another team working at the same site (Lahoutifard et al., 2003). However, an important 
increase was recorded on 7 June, reaching $88 \pm 39$ pmol L ${ }^{-1}$ (Fig. 2). This increase in total Hg in snow coincided with a mercury depletion event recorded at the same site (Fig. 2; Lahoutifard et al., 2003). Total Hg concentrations decreased by $92 \%$ (down to 7.5 pmol L ${ }^{-1}$ ) within $48 \mathrm{~h}$ after the event had ended.

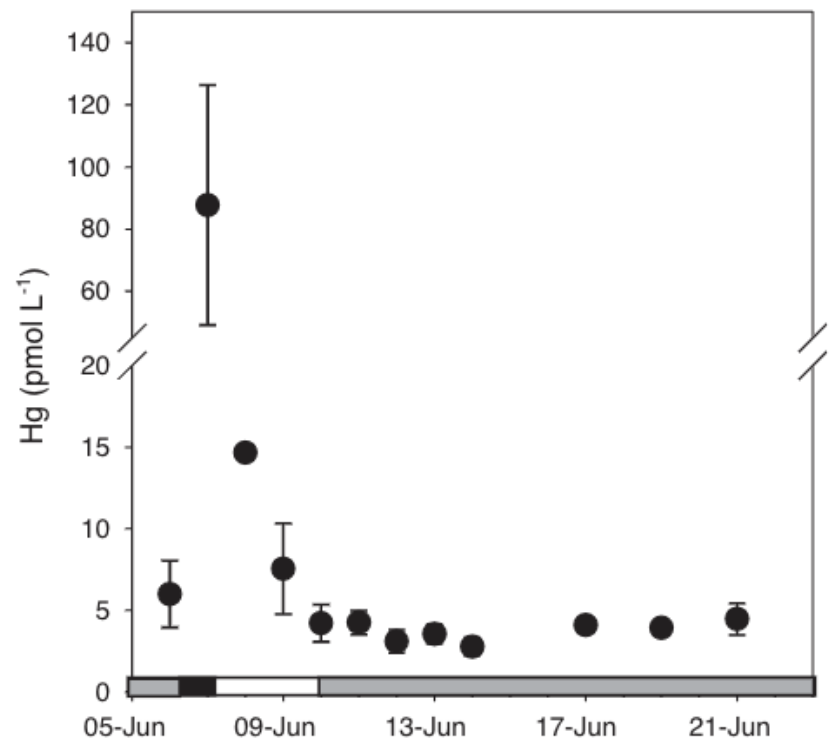

Fig. 2. Temporal variation of total $\mathrm{Hg}$ concentrations at the surface of the snowpack from 6 June to 21 June 2003. At the bottom of the graph, black horizontal bar represent sharp depletion of $\mathrm{Hg}(0)_{\text {atm }}$ concentrations $\left(0-1 \mathrm{ng} \mathrm{m}^{-3}\right)$, grey horizontal bars represent $\mathrm{Hg}_{\text {atm }}$ concentrations (between 1 and $3 \mathrm{ng} \mathrm{m}^{-3}$ ), and white bar represent high concentrations of $\mathrm{Hg}(0)_{\mathrm{atm}}\left(3-8 \mathrm{ng} \mathrm{m}^{-3}\right)$. The length of the bars is representative of the duration of the event. Vertical bars represent the standard deviation of three replicates.

Depth profiles of total $\mathrm{Hg}$ in the snowpack were measured on 7 and 14 June. On both dates, total Hg concentrations were higher in the top $5 \mathrm{~cm}$ than at depth (Fig. 3A and B). Note that arctic snowpacks usually undergo rapid transformations and that one should not assume that snow strata are totally conserved between sampling dates. 


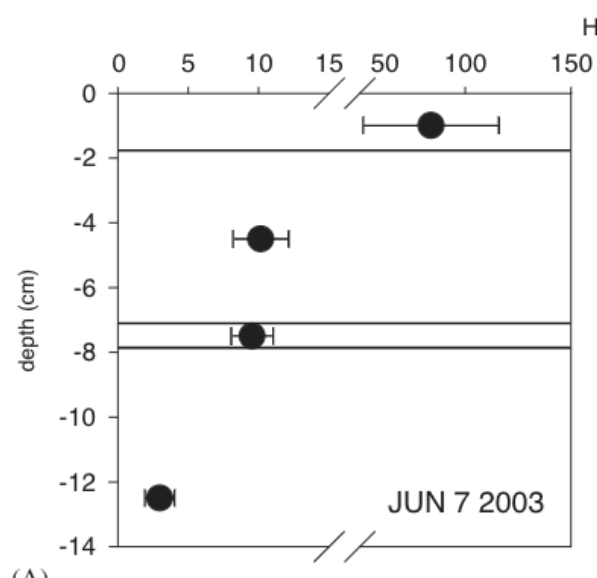

(A)

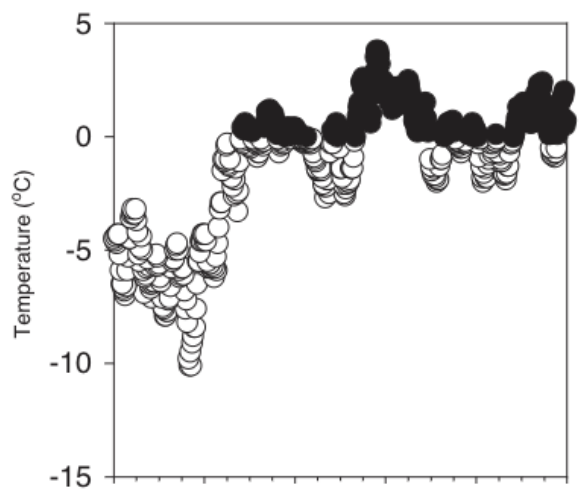

$\mathrm{Hg}\left(\mathrm{pmol} \mathrm{L}{ }^{-1}\right)$

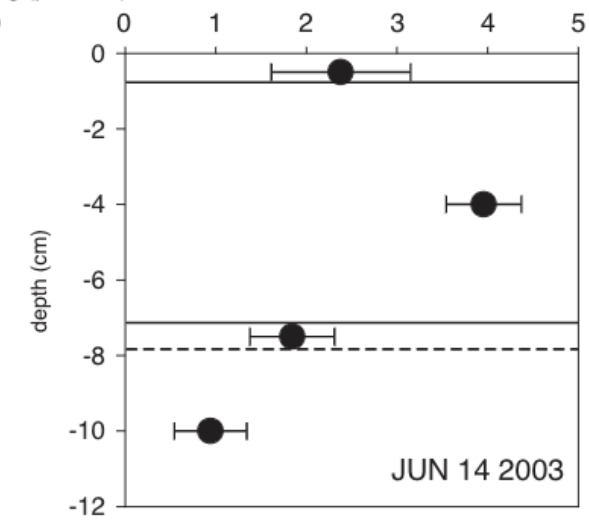

(B)

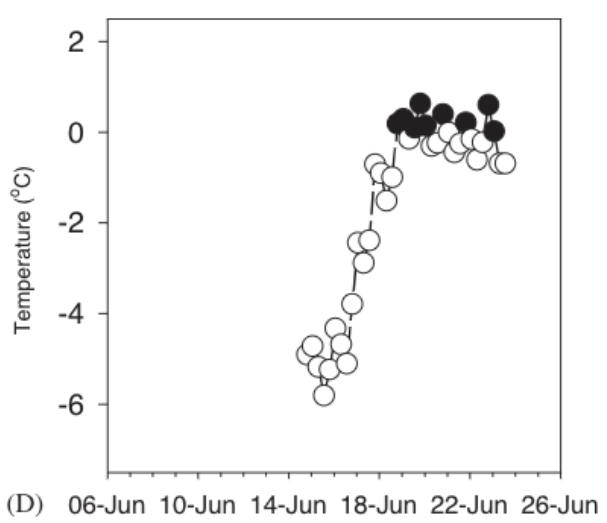

Fig. 3. Depth profiles carried out on 7 June (A) and 14 June (B). Temporal variation of the temperature at the surface (C) and at the bottom $(14 \mathrm{~cm})$ of the snowpack (D). Bars represent the standard deviation of three replicates.

The profile carried out on 7 June (Fig. 3A), exhibited Hg concentrations at the surface approximately a hundred times higher than at depth. At the surface, snow grains were needle-like and faceted, lightly metamorphosed, characteristic of freshly deposited crystals (Table 3). At depth, crystals were cup-shaped, characteristic of an advanced constructive metamorphism (Colbeck et al., 1985).

Table 3

State of metamorphism and physical properties of different snow strata on (A) 7 June and (B) 14 June 2003

\begin{tabular}{lllll}
\hline Snow stratum & Temperature $\left({ }^{\circ} \mathrm{C}\right)$ & Water content $(\%)$ & Grain type & Grain size (mm) \\
\hline (A) 7 June & & & & \\
S & -5 & 20 & Small faceted and needle-like & 0.5 \\
S-1 & -4 & 25 & Cup shaped & $0.5-2$ \\
S-2 & n/a & 90 & Ice crust & n/a \\
S-3 & -8 & 28 & Cup shaped & $2-3$ \\
(B) 14 June & & 36 & Rounded some faceted & $1-2$ \\
S & 0 & 50 & Rounded & 2 \\
S-1 & -4 & 90 & Ice crust & n/a \\
S-2 & n/a & 37 & Cup shaped & $3-4$ \\
S-3 & -8 & & & \\
\hline
\end{tabular}

On 14 June (Fig. 3B), the two first strata were representative of a single snowfall event. The depth profile on 14 June was determined after the unique important snow fall we encountered $(7 \mathrm{~cm})$. Crystals were mainly rounded, typical 
of warmer temperatures (which induce a quick destructive metamorphism), with few precipitation crystals still visible. This was seen as temperatures at the surface of the snowpack on 14 June were above $0{ }^{\circ} \mathrm{C}$ (Fig 3C).

From 12 June to 26 June, surface temperatures were above the freezing point during the day (Fig. 3C). Total $\mathrm{Hg}$ concentrations were higher in the pond created by melt water $\left(14\right.$ pmol L$\left.{ }^{-1}\right)$ and in the adjacent slush $\left(10 \mathrm{pmol} \mathrm{L}^{-1}\right)$ than in the solid snow itself (4 pmol $\left.{ }^{-1}\right)($ Fig. 4A). The fairly high total mercury concentrations encountered in pond water were likely a consequence of soil leaching, as corroborated by the increase in $\mathrm{Mg}^{2+}$ and $\mathrm{Ca}^{2+}$ concentrations, compared to surface snow ([Mg $\left.{ }^{2+}\right]_{\text {snow }}=0.96 \mathrm{mg} \mathrm{L}^{-1}, \quad\left[\mathrm{Mg}^{2+}\right]_{\text {pond }}=4.48 \mathrm{mg} \mathrm{L}^{-1}, \quad\left[\mathrm{Ca}^{2+}\right]_{\text {snow }}=3.63 \mathrm{mg} \mathrm{L}^{-1}$, $\left.\left[\mathrm{Ca}^{2+}\right]_{\text {pond }}=14.1 \mathrm{mg} \mathrm{L}^{-1}\right)$.
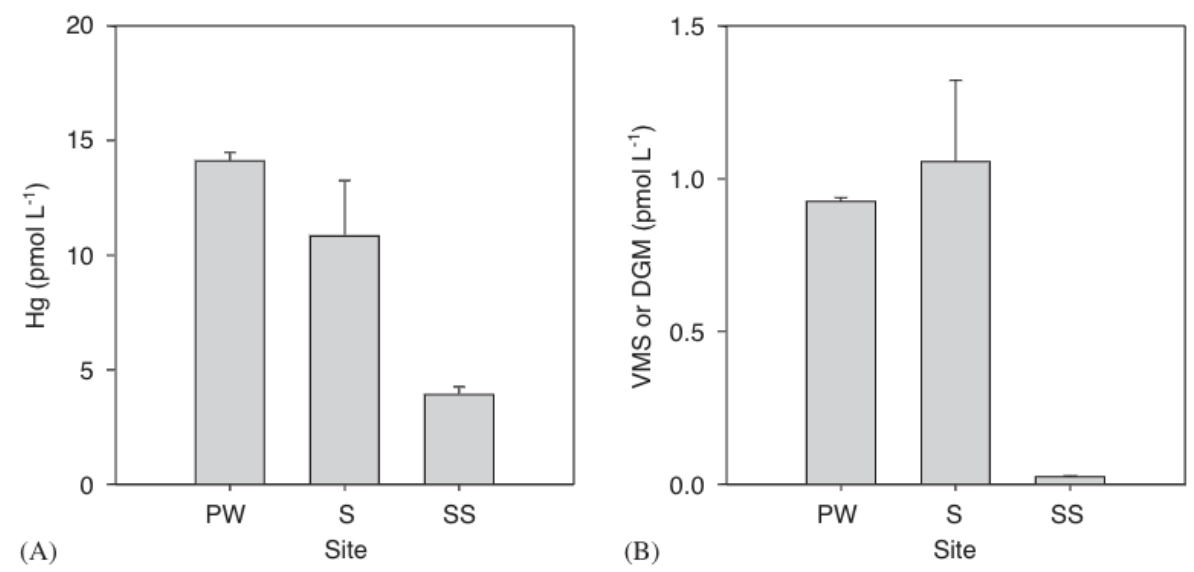

Fig. 4. Total Hg (A) and VMS or DGM (B) concentrations in a pond of Cornwallis Island (PW: pond water, S: slush, SS: surface snow).

VMS concentrations in surface snow were generally very low and close to the detection limit $\left(0.01 \mathrm{pmol} \mathrm{L}^{-1}\right)$ (Fig. 4B). VMS concentrations in the snow were lower than VMS in slush and dissolved gaseous mercury (DGM) in pond water.

\subsection{VMS production}

During incubation experiments conducted on 9 June, VMS concentrations in snow samples kept at the surface did not simply increase with time of exposure to solar radiation. Instead, they co-varied with short-term changes in PAR intensity (Fig. 5). We averaged PAR data (recorded every minute) over intervals of 5, 15, 30 and 60 min preceding the end of the incubation of each sample (referred to below as $\mathrm{PAR}_{t}$, where $t$ is the period for which data were averaged). PAR averaged over short intervals $\left(\mathrm{PAR}_{5 \mathrm{~min}}\right.$ and $\mathrm{PAR}_{15 \mathrm{~min}}$ ) better explained the variations observed in VMS concentrations $\left(\mathrm{r} 2=0.77 ; \mathrm{p}=0.0012\right.$ and $\mathrm{r} 2=0.72 ; \mathrm{p}=0.0023$, respectively) (Fig. 6 A and $\mathrm{B}$ ) than $\mathrm{PAR}_{30}$ min and $\mathrm{PAR}_{60} \min (\mathrm{r} 2=0.5 ; \mathrm{p}=0.018$ and $\mathrm{r} 2=0.38 ; \mathrm{p}=0.045$, respectively) (Fig. $6 \mathrm{C}$ and D). No increase in [VMS] was observed in snow incubated at a depth of $3 \mathrm{~cm}$, in contrast to the increase observed in samples exposed to direct sunlight (Fig. 5). In all experiments, no increase was observed when samples were kept in the dark (ig. 5, Fig. 7, Fig. 8). 


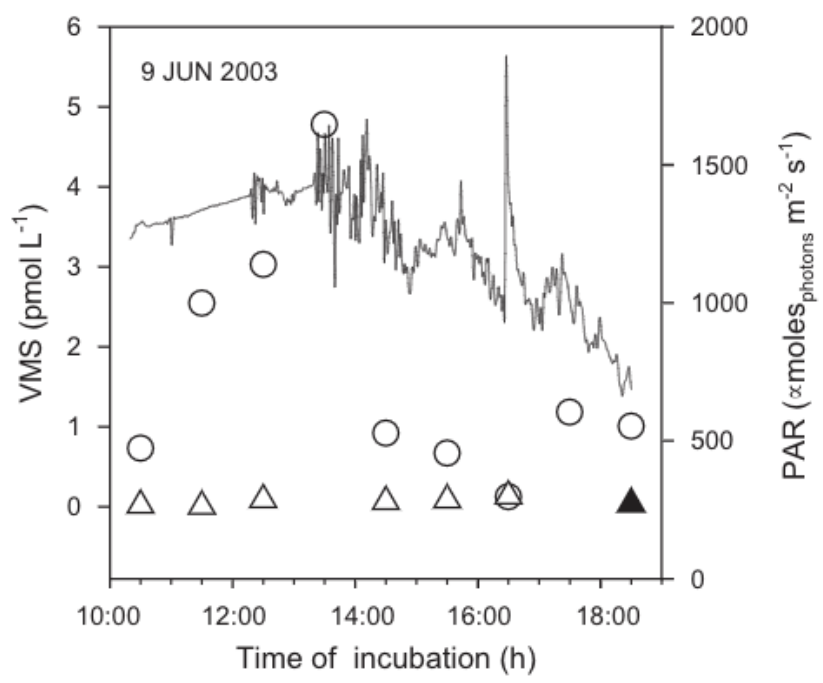

Fig. 5. Time series of VMS concentrations in snow over time of exposure to the sun on 9 June 2003. Open circles represent samples incubated at the surface of the snowpack. Open triangles represent samples incubated under $3 \mathrm{~cm}$ of snow. The black triangle represents samples kept in the dark.

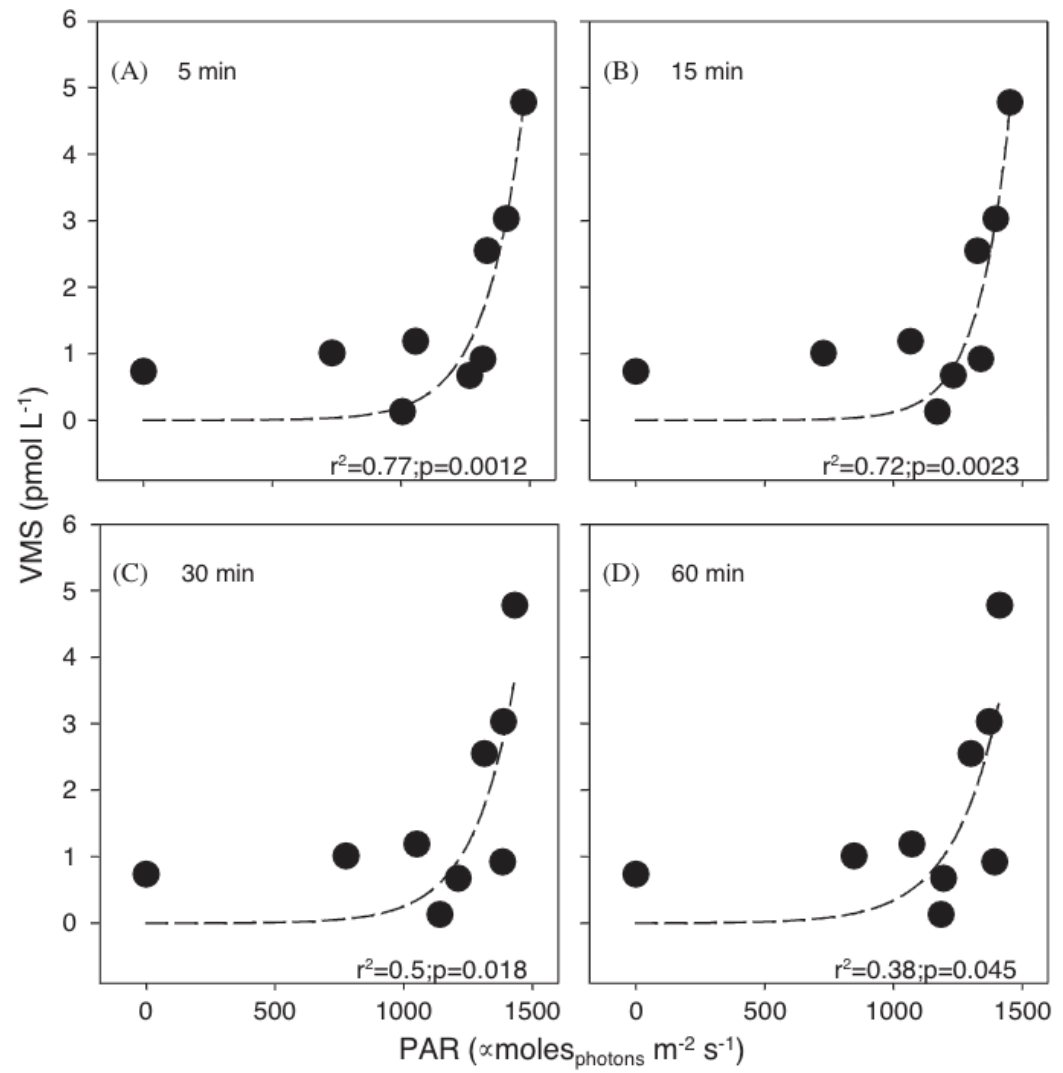

Fig. 6. Non-linear regression between VMS concentrations and PAR averaged 5 (A), 15 (B), 30 (C) and 60 (D) minutes before the end of the incubation for each samples. All regression were significant at the 0.05 level. Regression equation is $[\mathrm{VMS}]=a \mathrm{e}^{(b \mathrm{PAR})}$. 


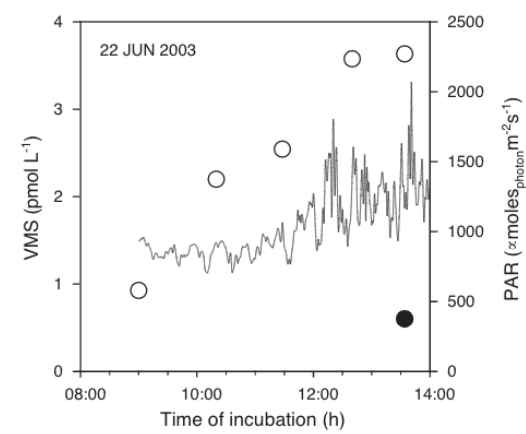

Fig. 7. Time series of VMS concentrations in pond water over time of exposure to the sun on 22 June 2003.
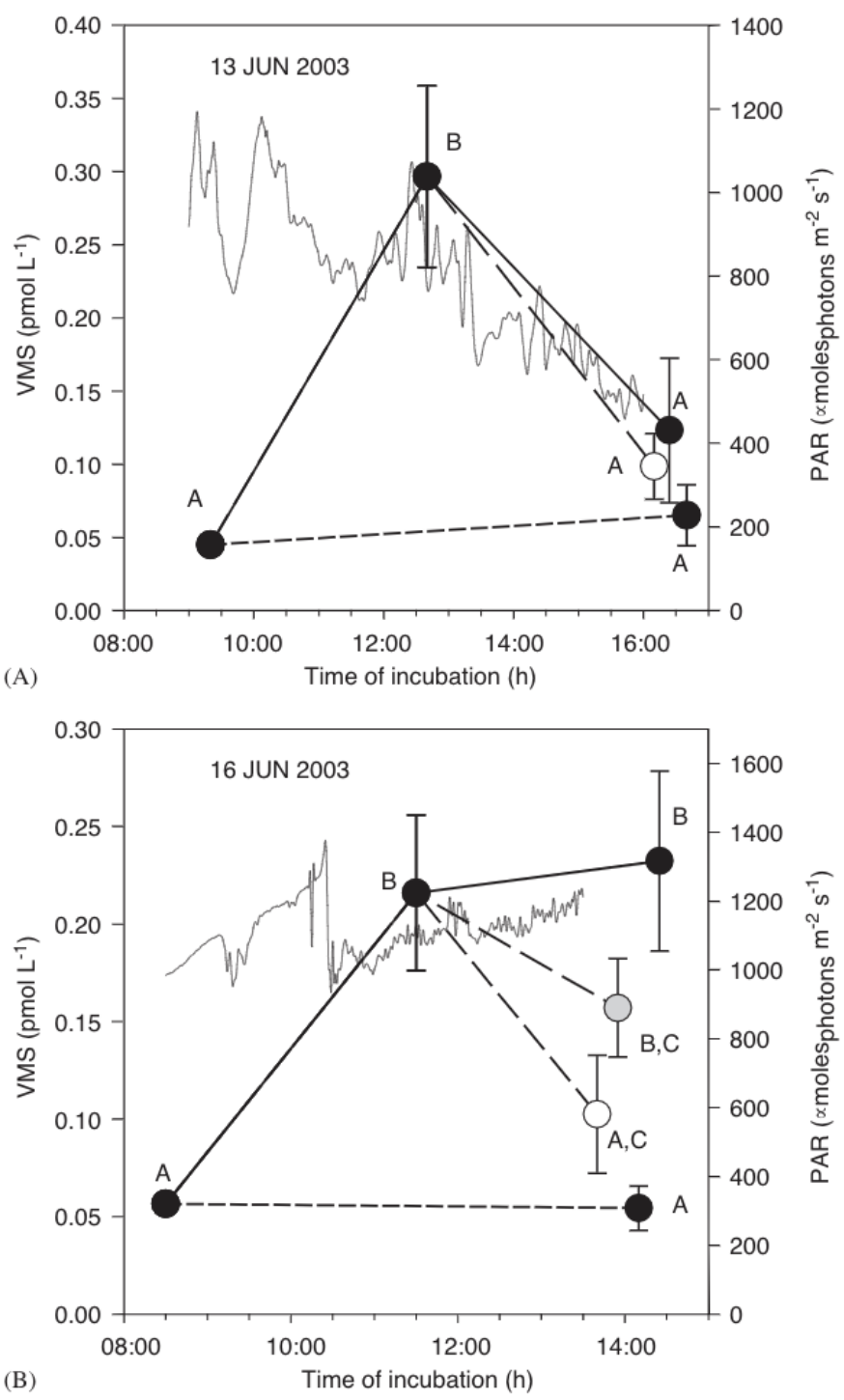

Fig. 8. Time series of VMS concentrations in snow on (A) 13 June and (B) 16 June 2003. In both cases the first step of the incubations led to the production of VMS after a first $3 \mathrm{~h}$ of exposure under the sun. On 13 June, after this initial exposure some samples were placed in the dark (closed circle) or kept uncover (open circle) for another $3 \mathrm{~h}$. On $16 \mathrm{June}$, after this initial exposure some samples were wrapped in Mylar filters (grey circle) in UV-Lee model 226 filters (open circle) or kept uncovered (closed circle) for another $2 \mathrm{~h}$. Letters referred to significant differences between treatments after an analysis of variance (ANOVA, systat 8.0). Vertical bars represent the standard deviation of three or four samples. 
An estimated maximum photoproduction rate was calculated based on the 9 June incubation (Fig. 5 ). After $3 \mathrm{~h}$ of exposure to the sun, concentrations reached $4.8 \mathrm{pmol} \mathrm{L}^{-1}$ corresponding to a photoproduction rate of $[\mathrm{VMS}]_{\text {prod }}=1.33 \mathrm{pmol} \mathrm{L}^{-1} \mathrm{~h}^{-1}\left([\mathrm{VMS}]_{0}=0.73 \mathrm{pmol} \mathrm{L}^{-1}\right)$.

Additional experiments were conducted with pond water. DGM concentrations in pond water increased when exposed to the sun leading to a photoproduction rate of $0.9 \mathrm{pmol} \mathrm{L} \mathrm{L}^{-1} \mathrm{~h}^{-1}$.

Note that destructive metamorphism was usually observed during incubation, since temperatures hovered around $0{ }^{\circ} \mathrm{C}$ (Fig. 3C). This phenomenon is typical of springtime conditions. Our results are therefore not necessarily representative of what may occur in dry and cold snow. It is likely that, when liquid water is formed, the rate of photoreduction of $\mathrm{Hg}(\mathrm{II})$ is altered (Schroeder et al., 2003).

\section{4. $\mathrm{Hg}(0)$ oxidation within the snowpack}

We observed [VMS] decreases over time in some incubation bottles (Fig. 5) which may have resulted from $\mathrm{Hg}(0)$ oxidation. We therefore conducted a series of experiments to assess the stability of newly formed $\mathrm{Hg}(0)$ in snow (Fig. 8). After $3 \mathrm{~h}$ of exposure to the sun, [VMS] increased by a factor 4 to 6 reaching 0.29 and $0.21 \mathrm{pmol} \mathrm{L}^{-1}$ on 13 and 16 June, respectively (Fig. 8A and B). After this initial incubation under the sun, some samples were placed in the dark and their [VMS] were monitored over three additional hours.

On 13 June, [VMS] measured in the dark decreased by $63 \%$ within $3 \mathrm{~h}$ (black circle, Fig. 8A). In samples kept uncovered, concentrations also decreased by $60 \%$ (white circle Fig. 8A). Note that this last incubation with uncovered bottles coincided with a strong snowfall and to a decrease of the PAR intensity (from $900 \mu \mathrm{mol}_{\text {photon }} \mathrm{m}^{-2} \mathrm{~s}^{-1}$ down to $500 \mathrm{mmol}_{\text {photon }} \mathrm{m}^{-2} \mathrm{~s}^{-1}$ ) at 1:00 pm on 13 June (Fig. 8A).

On 16 June, we applied filters to snow samples previously incubated for $3 \mathrm{~h}$ under the sun. When samples were wrapped in Mylar (no UV-B treatment), [VMS] decreased by $30 \%$ over a $2 \mathrm{~h}$ period (grey circle, Fig. 8B). When samples were wrapped in UV-Lee filters (no UV treatment), [VMS] decreased by 56\% (open circles, Fig. 8B). When samples were kept exposed to direct sunlight, concentrations did not decrease, but reached a plateau at a value of 0.23 pmol L ${ }^{-1}$ (black circle, Fig. 8B). During this experiment no major continuous PAR decrease was recorded and the mean daily PAR was around $1150 \mu \mathrm{mol}_{\text {photon }} \mathrm{m}^{-2} \mathrm{~s}^{-1}$, with peaks reaching $1500 \mu \mathrm{mol}_{\text {photon }} \mathrm{m}^{-2} \mathrm{~s}^{-1}$ (Fig. $\left.8 \mathrm{~B}\right)$. No changes in [VMS] were recorded in samples kept in total darkness for $5 \mathrm{~h}$. Note that these experiments were conducted under springtime conditions, i.e. at near zero temperature; the snow was therefore undergoing destructive metamorphism.

\section{Discussion}

\subsection{Chemistry of snowpacks from the resolute bay area}

\subsubsection{Distribution of inorganic ions}

The prevalence of anions (chloride, nitrate and sulphate) and cations (calcium, sodium and magnesium) observed at Resolute from 4 June to 26 June agreed well with the results of a previous study on the chemical composition of arctic snowfall (Toom-Sauntry and Barrie, 2002). The prevalence of chloride, nitrate and sulphate is likely the result of both sea-salt and acid aerosol deposition. The predominance of calcium, sodium and magnesium was probably due to the deposition of both sea-salt and soil or dust aerosols (the bedrock is of calcareous origin). Indeed, mid-June snowpacks started to melt (Fig. 3C) exposing large areas of bare soil.

\subsubsection{Variety of organic molecules}

The probable origins of organics in the arctic snow include: (a) long range transport of volatile compounds or of species associated with aerosols originating from southern areas, (b) transport of aerosols formed over the Arctic ocean (Leck et al., 2002), (c) local deposition of organic aerosols from soil or decaying biota (Kawamura et al., 1996) (d) the biological and/or photochemical transformations of the previous compounds (Ariya et al., 2002, $\underline{\text { Ariya et al., 2002) }}$ and (e) directly from bioaerosols (Ariya and Amyot, 2004). Several unidentified peaks were observed in mass spectra 


\section{https://www.sciencedirect.com/science/article/pii/S1352231004008544}

of snow samples, some of which could correspond to larger molecular weight organic molecules such as peptides and polysaccharides. The smaller organic compounds observed in this study are expected to be formed via oxidation of dissolved organic matter or from biological-chemical or photochemical reactions of organics (Sumner and Shepson, 1999; Ariya et al., 2002, Ariya et al., 2002).

A few identified organic compounds exhibit high vapour pressure (e.g. chlorobenzene; 1-ethyl, 3-methyl benzene) and one expects a flow of such molecules from snowpack to atmosphere. Some other identified organic compounds, particularly long chain aldehydes, ketones and aromatic compounds, should be retained in the snow. Based on the chemical structure of these groups, one can expect the production of a variety of organic intermediates, including radicals, in presence of large pools of oxidant precursors such as halides, $\mathrm{NO}_{2}{ }^{-}$and $\mathrm{NO}_{3}{ }^{-}$; these precursors can release active halogens and HO radicals in snow, upon photolysis. The production of such radicals will likely lead to changes in the redox chemistry of $\mathrm{Hg}$, as discussed below (see Section 4.3.).

\subsection{Behaviour of $\mathrm{Hg}$ in snow after the atmospheric $\mathrm{Hg}$ depletion event}

At the exception of a peak recorded on 7 June, total $\mathrm{Hg}$ concentrations in snow stayed below 15 pmol $\mathrm{L}^{-1}$ from 7 June to 23 June. The sharp increase on 7 June was likely the result of a depletion event of atmospheric mercury $(\mathrm{Hg}(0)$ atm $)$, since such an event was observed by another team working at the same site at the same time (Lahoutifard et al., 2003). Total $\mathrm{Hg}$ concentrations in surface snow then decreased by $92 \%$ within $48 \mathrm{~h}$.

As initially demonstrated by Lalonde et al. (2002), total Hg loss in surface snow likely resulted from a snow-to-air rather than a snow-to-ground transfer. Indeed, $\operatorname{Hg}(0)_{\text {atm }}$ concentrations over the snowpack sharply increased after 7 June (Lahoutifard et al., 2003) and no increase in total mercury concentrations was observed deeper in the snowpack after this event (Fig. $3 \mathrm{~A}$ and B). Note that, polar snowpacks are typically exposed to high winds, and therefore undergo continuous changes, making it difficult to follow a specific snow layer over time (Hanot and Dominé, 1999).

We assessed if daily losses of total $\mathrm{Hg}$ following the MDE could be accounted for by VMS photoproduction. From 9 June to 10 June $\left(24 \mathrm{~h}\right.$ period), total $\mathrm{Hg}$ concentrations at the surface of the snowpack decreased by $3.3 \mathrm{pmol} \mathrm{L}^{-1}$ (Fig. 2). On 9 June, incubation experiments yielded a VMS production of 3.9 pmol L ${ }^{-1}$ over the daily peak of solar radiation (10h00 to 18h00). VMS photoproduction can therefore account for more than the observed loss in total Hg. Note that these are rough estimates, since $\mathrm{Hg}$ photooxidation will also affect both losses of total $\mathrm{Hg}$ in snow and VMS production in incubation bottles.

No increase in [VMS] was observed in samples incubated under $3 \mathrm{~cm}$ of snow or kept in the dark, suggesting that Hg photoreduction occurred at the very surface of the snowpack. According to King and Simpson (2001), we would expect that approximately $75 \%$ of incident UV radiation will penetrate to a depth of $3 \mathrm{~cm}$. It is therefore surprising that we observed no photochemically-induced VMS production at $3 \mathrm{~cm}$. King and Simpson's results may not be directly applicable to our study, due to differences in snow type and light penetration patterns. They indeed studied 
https://www.sciencedirect.com/science/article/pii/S1352231004008544

very dry snow at $-30{ }^{\circ} \mathrm{C}$; these conditions would have favoured light penetration. VMS production may also be partly governed by heterogeneous catalysis or by biological catalysis of a biofilm at this interface.

\subsection{Photooxidation and reduction of mercury}

The incubations showed that after an initial increase in [VMS] in samples exposed to the entire solar spectrum, subsequent removal of UV-B radiation led to a decrease in [VMS] of $30 \%$ (Fig. 8). The removal of both UV-B and UV-A radiation and of all radiations led to decreases of $56 \%$ and $63 \%$, respectively.

These results indicate that $\mathrm{Hg}$ reduction was mainly driven by UV-B radiation. This is in agreement with previous findings in remote temperate locations (Lalonde et al., 2003). We further observed an oxidation of newly photoproduced $\mathrm{Hg}(0)$. If pre-exposed samples were kept in the dark, exposed to UV-A or visible wavebands, oxidation was favoured over reduction. Our observations illustrate that under low UV-B exposure, one can indeed detect the signature of mercury oxidation.

We identified several organic molecules and halides that could potentially act as oxidants of $\mathrm{Hg}$ under these conditions (Table 1, Table 2). Evidence for the existence of reactive radicals such as $\mathrm{HO}, \mathrm{Cl}$, and $\mathrm{Br}$ upon photolysis in snowpack has already been presented (Ariya et al., 1999; Sumner and Shepson, 1999). Many such radicals can be produced by irradiation within the UV-A or visible spectra (e.g., $\mathrm{Cl}$ can be produced by UV-A photolysis of $\mathrm{Cl}_{2}$, while $\mathrm{Br}$ can be generated by visible photolysis of $\mathrm{Br}_{2}$ ). They can also lead to production of other organic radical intermediates. We therefore can speculate that, due to the presence of the reactive radicals, a set of reactions can supply oxidants to transform $\mathrm{Hg}(0)$ to $\mathrm{Hg}(\mathrm{II})$. Clearly, since mercury redox mechanisms are complex, one also expects reduction of oxidized mercury to occur simultaneously.

\section{Conclusion}

We propose that during arctic springtime, both reduction and oxidation of $\mathrm{Hg}$ occurs in snowpacks and are both photoinduced. According to our results, the reactions occur at the surface, likely through a chain reaction after the formation of initial radicals. Newly produced VMS that is not quickly exported to the atmosphere is likely to remain within the snowpack because of re-oxidation. $\mathrm{Hg}$ travelling throughout the snowpack in its volatile reduced form will alternatively undergo oxidation and reduction when reaching the surface, where pools of photolabile molecules are found. Wind intensity and the extent of its penetration within the snowpack as well as a good knowledge of the physical properties of the snowpack, such as temperature gradients that can control the distribution of volatile species, are therefore critical parameters to better model $\mathrm{Hg}$ behaviour in snow especially in the High Arctic where snow undergoes a rapid and constant metamorphism.

\section{Acknowledgements}

We gratefully acknowledge funding from CFCAS and COMERN to MA and PAA. We thank Peter G.C. Campbell for his comments on the manuscript. We also would like to thank the Polar Continental Shelf Project for their 


\section{https://www.sciencedirect.com/science/article/pii/S1352231004008544}

outstanding logistic help as well as the Nunavut Research Institute that delivered our research license. We thank Melissa Sparling and Debbie Iqaluk for their help in the field.

\section{References}

Ariya, P.A., Hopper, J.F., Harris, G.W., 1999. C-2-C-7hydrocarbon concentrations in arctic snowpack interstitialair: Potential presence of active Br within the snowpack.Journal of Atmospheric Chemistry 34 (1), 55-64.

Ariya, P.A., Khalizov, A., Gidas, A., 2002. Reactions ofgaseous mercury with atomic and molecular halogens:kinetics, product studies, and atmospheric implications.Journal of Physical Chemistry A 106, 7310-7320.

Ariya, P.A., Nepotchatykh, O., Ignatova, O., Amyot, M., 2002.Microbiological degradation of organic compounds in theatmosphere. Geophysical Research Letter 29 (22) Art. No.2077.

Ariya, P.A., Amyot, M., 2004. Ne wdirections: The role ofbioaerosols in atmospheric chemistry and physics. Atmo-spheric Environment 38, 12311232 .

Colbeck, S., Akitaya, E., Armostrong, R., Gubler, H.,Lafeuille, J., Lied, K., McClung, D., Morris, E., 1985.The international classification for seasonal sno won theground. The International Commission on Sno wand Ice ofthe International Association of scientific Hydrology andthe International Glaciology Society.

Dommergue, A., Ferrari, C.P., Poissant, L., Gauchard, P.A.,Boutron, C., 2003. Diurnal cycles of gaseous mercury withinthe snowpack at Kuujjuarapik /Whapmagoostui, Quebec,Canada. Environmental Science and Technology 37,3289-3297.

Ebinghaus, R., Kock, H.H., Temme, C., Einax, J.W., Lowe,A.G., Richter, A., Burrows, J.P., 2002. Antarctic SpringtimeDepletion of Atmospheric Mercury. Environmental Scienceand Technology 36, 1238-1244.

Ferrari, C.P., Dommergue, A., Boutron, C.F., Skov, H.,Goodsite, M., Jensen, B., 2004. Nighttime production ofelemental gaseous mercury in interstitial air of sno watStation Nord, Greenland. Atmospheric Environment 38,2727-2735.

Gill, G.A., Bruland, K., 1990. Mercury in freshwater systems in California and other areas. Environmental Science andTechnology 24, $1392-1400$.

Hanot, L., Domine', J., 1999. Evolution of the surface Area of a Snowlayer. Environmental Science and Technology 33,4250-4255.

Kawamura, K., Kasukabe, H., Barrie, L.A., 1996. Source and reaction pathways of dicarboxylic acids, ketoacids anddicarbonyls in arctic aerosols: one year of observations. Atmospheric environment 30 (10-11), 1709-1722.

King, M.D., Simpson, W.R., 2001. Extinction of UV radiationin Arctic sno wat Alert, Canada (821N). Journal ofGeophysical Research 106 (D12), 12499-12507.

Lahoutifard, N., Sparling, M.C., Lean, D.R.S., 2003. "Inter-relationships between atmospheric mercury, mercury speciation in the sno wand springtime weather conditionsin the High Arctic": COMERN fourth General meeting,5-7 November. Fairmount Algonquin-St Andrew's (NB),Canada.

Lalonde, J.D., Amyot, M., Kraepiel, A.M.L., Morel, F.M.M.,2001. Photooxidation of $\mathrm{Hg}(0)$ in artificial and naturalwaters. Environmental Science and Technology 35,1367-1372.

Lalonde, J.D., Poulain, A.J., Amyot, M., 2002. The role ofmercury redox reactions in snowon sno w-to-air mercurytransfer. Environmental Science and Technology 36,174-178.

Lalonde, J.D., Amyot, M., Doyon, M.R., Auclair, J.C., 2003.Photo-induced Hg(II) reduction in sno wfrom the remoteand temperate experimental lakes Area (Ontario, Canada).Journal of Geophysical Research-Atmospheres 108 (D6)Art. No. 4200.

Lalonde, J.D., Amyot, M., Orvoine, J., Morel, F.M.M.,Auclair, J.C., Ariya, P.A., 2004. Photoinduced oxidationof Hg-0 (aq) in the waters from the St. Lawrence estuary. Environmental Science and Technology 38 (2),508-514.

Leck, C., Norman, M., Bigg, E.K., Hillamo, R., 2002. Chemicalcomposition and sources of the high Arctic aerosol relevantfor cloud formation. Journal of Geophysical Research-Atmospheres 107 (D12) Art. No. 4135.

Lindberg, S.E., Brooks, S., Lin, C.J., Scott, K.J., Meyers, T.,Chambers, L., Landis, M., Stevens, R., 2001. Formation ofreactive gaseous mercury in the arctic: evidence of oxidationof $\mathrm{Hg}(0)$ to gas-phase $\mathrm{Hg}$-II compounds after arctic sunrise. Water Air and soil Pollution, Focus 1, $295-302$.

Lindberg, S.E., Brooks, S., Lin, C.J., Scott, K., Landis, M.,Stevens, R., Goodsite, M., Richter, A., 2002. Dynamicoxidation of gaseous mercury in the Arctic troposphere atpolar sunrise. Environmental Science and Technology 36,1245-1256. 
Lu, J.Y., Schroeder, W.H., Barrie, L.A., Steffen, A., Welch,H.E., Martin, K., Lockhart, L., Hunt, R.V., Boila, G.,Richter, A., 2001. Magnification of atmospheric mercurydeposition to Polar Regions in springtime: the link totropospheric ozone depletion chemistry. Geophysical Re-search Letters 28 (17), 3219-3222.

Poissant L., Pilote M., 2003. Time series analysis of atmo-spheric mercury in Kuujjuarapik/Whapmagoostui (Que-bec). Journal de physique IV, 107: 1079-1082 Part 2

Schroeder, W.H., Anlauf, K.G., Barrie, L.A., Lu, J.Y., Steffen,A., 1998. Arctic springtime depletion of mercury. Nature394, 331-332.

Schroeder, W.H., Steffen, A., Scott, K., Bender, T., Prestbo, E.,Ebinghaus, R., Lu, J.Y., Lindberg, S.E., 2003. Conferencereport; Summary Report: first international Arctic atmo-spheric mercury research workshop. Atmospheric Environ-ment 37, 2551-2555.

Scott, K.J., 2003. Development and use of amer-luxbioreporter for the measurement and characterization ofbioavailable $\mathrm{Hg}$ (II) in defined media and aquatic environ-mental samples. Ph.D. thesis. University of Manitoba,Winnipeg, Manitoba, Canada 152pp.

Steffen, A., Schroeder, W., Bottenheim, J., Narayan, J.,Fuentes, J.D., 2002. Atmospheric mercury concentrations:measurements and profiles near sno wand ice surfaces in the Canadian Arctic during Alert 2000. Atmospheric Environ-ment 36, 2653-2661.

Sumner, A.L., Shepson, P.B., 1999. Snowpack production offormaldehyde and its effect on the Arctic troposphere.Nature 398 (6724), $230-233$.

Toom-Sauntry, D., Barrie, L.A., 2002. Chemical compositionof snowfall in the high Arctic: 1990-1994. AtmosphericEnvironment 36, 2683-2693 